\title{
In vitro Propagation of Cleome gynandra L. using Nodal Explants
}

\author{
Sudan, I. $^{1}$, Karthikeyan, A.V.P. ${ }^{2}$ \\ P.G. and Research Department of Botany, Government Arts College (Autonomous), Karur 639 005, Tamilnadu, India
}

\begin{abstract}
Mass propagation in plants of Cleome gynandra L. were regenerated from nodal explants on MS medium containing various concentration of cytokinins (BAP and KIN) ranging from $5 \mu M$ to $25 \mu M$. When compared to KIN, BAP was found to act in response well in shoot multiplication and number of shoots. Large number of shoots was produced from all concentration of BAP and KIN. Maximum number of shoots and highest frequency of $100 \%$ shoot induction was observed on MS medium containing $10 \mu M$ KIN and $B A P$. The elongated shoots were then transferred to MS half strength medium augmented with NAA and IAA in various concentrations for root induction. The roots were initiated and well developed in $2 \mu M$ of both the auxins.
\end{abstract}

Keywords: Cleome gynandra L., BAP, KIN, IAA, NAA, Micropropagation

\section{Introduction}

The plant Cleome gynandra Linn (Fam: Cleomaceae) (Syn. Gynandropsis gynandra.L., Gynandropsis pentaphylla L.), is commonly known as „Hurhureand,Karaila ${ }^{e e}$ in India and "Cat"s whiskerse in English. Velai keerai, Thaivelai in Tamil, it is an annual, erect, branched, 0.6-1.2 $\mathrm{m}$ in height, stems and branches striate, white spreading hairs. Leaves 35 foliolate, petioles $5-7.6 \mathrm{~cm}$ long, and seeds muricate dark [1]. Cleome gynandra is used as a medicinal plant and can be found in all over world. It grows as a weed in paddy fields and also in roadsides and in open grass lands [2]-[4]. In India it is not at all cultivated but grows unexpectedly all over the place. Different species of Cleome can be found in all states of India.

In the literature of pharmacopoeia of India and also in other ancient medical texts describe that the medicinal application of Cleome gynandra $\mathrm{L}$ is an important medicinal plant in Ayurveda. In Ayurvedic medicine these plant is a chief constituent in Narayana Churna [5]-[7]. Natural products are identified to take part in an important role in both drug discovery and chemical biology. Though some therapeutic benefits can be traced from the specific plant compounds, most of herbs contain several active phytochemical constituents; they are all therapeutic value either individually or in combination. In vitro clonal propagation is only the alternative way for the regeneration and expedites release of large number of $C$. viscosa plants under aseptic culture conditions. Earlier, there have been few reports on establishment of in vitro propagation through callus culture of C. viscosa [8-9], micropropagation and shoot organogenesis from different explants of Cleome spinosa [10] [13] and Cleome gynanadra [14], somatic embryogenesis [15] cell suspension and root culture with cryopreservation of $C$. rosea [16]. The present study was carried out to standardize a protocol for in vitro propagation of $C$. gynandra from nodal explants.

\section{Materials and Methods}

\subsection{Sample collection}

The plants of Cleome gynandra L. were collected from road sides of Thanthonimalai village, Karur District, Tamil Nadu,
India and the name was confirmed with the help of Rapinat Herbarium, St. Joseph "es College, Tiruchirappalli . The samples were washed thoroughly in running tap water to remove soil particles and adhered debris and finally washed with sterile distilled water.

\subsection{Media Preparation}

The Murashige and Skoog basal medium consisted of the mineral salts and organic nutrients of B5 vitamins with 3\% sucrose and $0.8 \%$ agar [17]. After adding all the supplements the basal media $\mathrm{pH}$ was adjusted to 5.8 by adding $0.1 \mathrm{~N} \mathrm{HCl}$ or $\mathrm{NaOH}$. The prepared media were poured in culture tubes or conical flasks and were closed with cotton plugs. The culture media were sterilized by autoclaving at $1.06 \mathrm{~kg} \mathrm{~cm}^{-3}$ and $121^{\circ} \mathrm{C}$ for $15-18 \mathrm{~min}$.

\subsection{Inoculation Procedure}

The nodal segments were isolated from the collected plants of $C$. gynandra L. These explants were surface sterilized by rinsing in running tap water for 30 minutes. Then they were washed in an agitated solution of liquid detergent (Teepol) for 5 minutes and distilled water for 2-3 times. After thorough washing, the materials were taken in to the laminar flow chamber where they were disinfected with $70 \%$ alcohol for $45 \mathrm{sec}$ followed by $0.1 \%$ mercuric chloride for 3 mins. Finally, the explants were thoroughly rinsed with sterile distilled water for 4-5 times to remove the surface traces of mercuric chloride. Finally, the nodal segments were placed on the medium.

\subsection{Shoot Induction}

For the shoot induction, young nodal region of the explants were transferred into the MS medium containing BAP (5 $\mu \mathrm{M}$ to $25 \mu \mathrm{M})$ or $\mathrm{KIN}(5 \mu \mathrm{M}$ to $25 \mu \mathrm{M}) \quad$ concentration individually. Shoot initiation was first recorded in the nodal region. The optimum $\%$ of shoots was obtained from nodal segments.

\subsection{Rooting}

In vitro raised shoots were excised and transferred to half strength MS medium supplemented with various 


\section{International Journal of Science and Research (IJSR) ISSN (Online): 2319-7064}

Index Copernicus Value (2015): 78.96 | Impact Factor (2015): 6.391

concentrations of Indole butyric acid (NAA: 2-10 $\mu \mathrm{M}$ ) or $\alpha$ Indole acetic acid (IAA:2-10 $\mu \mathrm{M}$ ).

\subsection{Culture Conditions and Maintenance}

The cultures were maintained in a culture room at $25 \pm 2^{\circ} \mathrm{C}$ under 16 hours photoperiod with light intensity of 30-40 $\mu \mathrm{M}$ $\mathrm{m}^{-2} \mathrm{~s}^{-\mathrm{I}}$ supplied by cool white fluorescent tubes. These growth conditions were referred to as standard culture conditions for in vitro studies. After 4 weeks of inoculation, the shoots were sub cultured on MS medium fortified with the same growth regulator concentrations and combinations or whichever is the best for further multiplication.

\subsection{Statistical analysis}

All above experiments were performed by a randomized completely block design and each experiment consisted of ten replicates and each experiment was repeated five times. The analysis of variance (ANOVA) appropriate for the design was carried out to detect the significance of differences among the treatment means were compared using Duncan's Multiple Range Test (DMRT) at a 5\% level of significance [18].

\section{Result and Discussion}

\section{Shoot, Root induction and multiplication}

The present study reported direct organogenesis of Cleome gynandra L. from nodal segment on MS medium supplemented with different concentrations of BAP or KIN. The nodal segments were initially grown on MS medium supplemented with BAP and KIN separately in different concentrations ranging from 5 - $25 \mu \mathrm{M}$ [19]-[21]. The Maximum number of shoots was achieved in 30-45 days. Among these, the maximum number of shoots $13.2 \pm 0.41$ was developed on MS media fortified with $10 \mu \mathrm{M}$ BAP, maximum shoot length was observed as $6.6 \pm 1.66 \mathrm{~cm}$ with $90 \%$ shoot sprouting frequency on a medium supplemented with $10 \mu \mathrm{M}$ BAP followed by $5 \mu \mathrm{M}$ BAP with $7.6 \pm 0.57$ shoots per explant and mean shoot length of $4.86 \pm 1.37 \mathrm{~cm}$ with $70 \%$ shoot induction frequency. The data in respect of shoot induction frequency, number of shoots and length of shoots on different concentrations of each hormone on node were presented in (Table.1, Fig.1a-c).

Table 1: Effect of different concentrations of cytokinins on shoot induction from the nodal explants of C. gynandra $\mathrm{L}$

\begin{tabular}{|c|c|c|c|c|}
\hline \multicolumn{2}{|c|}{$\begin{array}{l}\text { Concentration of } \\
\text { cytokinins }\end{array}$} & \multirow{2}{*}{$\begin{array}{c}\text { Shoot } \\
\text { Induction } \\
\text { Frequency } \\
(\%)\end{array}$} & \multirow{2}{*}{$\begin{array}{l}\text { Number of } \\
\text { Shoots }\end{array}$} & \multirow{2}{*}{$\begin{array}{l}\text { Shoot Length } \\
(\mathrm{cm})\end{array}$} \\
\hline $\begin{array}{l}\text { BAP } \\
(\mu \mathrm{M})\end{array}$ & $\mathrm{KIN}(\mu \mathrm{M})$ & & & \\
\hline 5 & --- & 70.0 & $8.6 \pm 0.57$ & $4.86 \pm 1.37$ \\
\hline 10 & --- & 90.0 & $13.2 \pm 0.41$ & $6.60 \pm 1.66$ \\
\hline 15 & --- & 66.6 & $7.6 \pm 0.40$ & $4.86 \pm 0.65$ \\
\hline 20 & --- & 63.3 & $4.75 \pm 0.47$ & $4.08 \pm 0.88$ \\
\hline 25 & --- & 53.3 & $3.8 \pm 0.41$ & $4.02 \pm 1.21$ \\
\hline--- & 5 & 66.6 & $8.5 \pm 0.28$ & $5.14 \pm 0.98$ \\
\hline--- & 10 & 80.0 & $9.75 \pm 0.47$ & $5.66 \pm 1.50$ \\
\hline--- & 15 & 83.3 & $11.75 \pm 0.75$ & $6.62 \pm 0.62$ \\
\hline--- & 20 & 50.0 & $5.6 \pm 0.57$ & $4.88 \pm 1.06$ \\
\hline--- & 25 & 46.6 & $4.4 \pm 0.44$ & $2.82 \pm 1.02$ \\
\hline
\end{tabular}

The basal medium containing different concentrations of KIN induced more or less similar number of shoots like BAP [22]. Maximum number of $11.75 \pm 0.75$ shoots per explants was proliferated on MS medium supplemented with $15 \mu \mathrm{M}$ KIN and mean shoot length $6.62 \pm 0.62 \mathrm{~cm}$ with $73.3 \%$ shoot induction frequency. Among these two cytokinins tested BAP was found to induce more number of shoots when compared to KIN. Similar to our findings, many researchers showed that BAP induced multiple shoot formation [23]-[24]. The shoot induction and proliferation depend on plant growth regulators and types of explants [25].

The shoots measuring about $3-5 \mathrm{~cm}$ in height were transferred to half-strength MS medium supplemented with various concentrations of NAA and IAA $(2-10 \mu \mathrm{M})$ for rooting. IAA is clearly more effective in promoting root induction than NAA. Rooting frequency, the number of roots per shoot and root length were highly influenced by type and concentration of auxin. Significant $(P<0.05)$ difference was found between different concentrations of both the auxins and increasing auxin concentration which promoted roots (Fig. 1d) [26-27].

Of the two auxins tested for root induction IAA was more responsive than NAA. Here, the results showed consistency with other studies where the addition of IAA promotes the induction of roots in several systems including Holarrhena antidysenterica [28]; Heliotropium kotschyi [29-30]. However, NAA was more effective auxins for root induction in Terminalia arjuna [31].

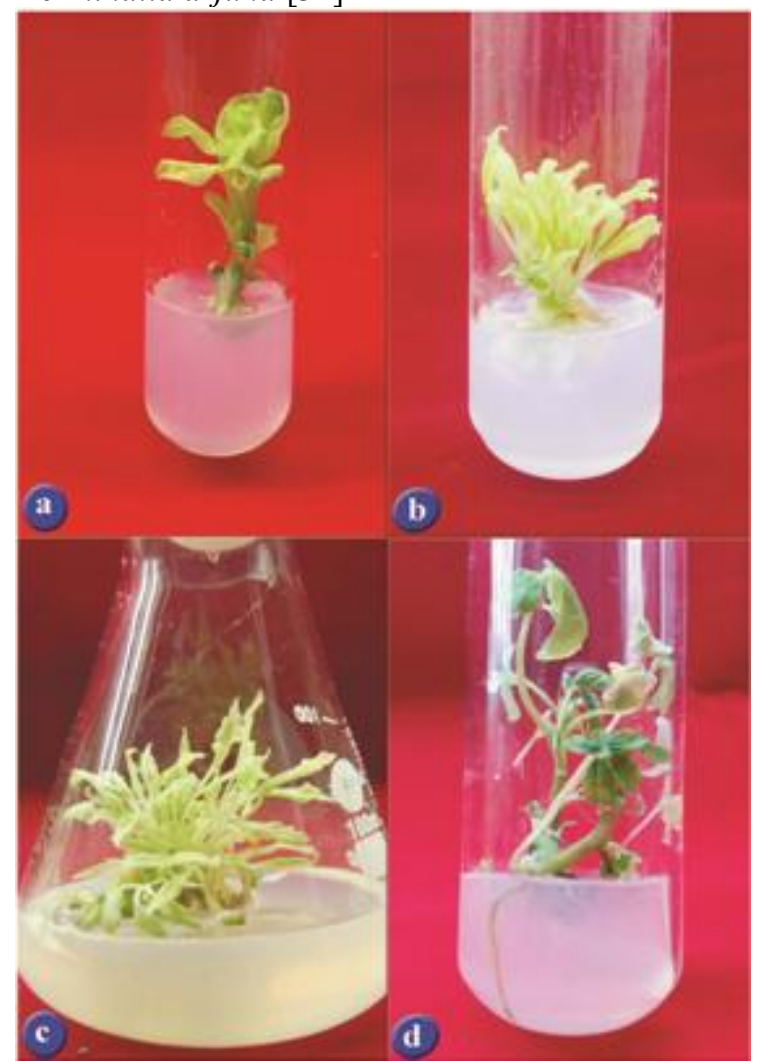

Figure 1: In vitro regeneration of $C$. gynandra L. a. Nodal explant growing on MS medium, b. \& c. Shoot multiplication and shoot proliferation, d. Root initiation. 


\section{International Journal of Science and Research (IJSR) \\ ISSN (Online): 2319-7064}

Index Copernicus Value (2015): 78.96 | Impact Factor (2015): 6.391

\section{Conclusion}

Micropropagation or Direct Organogenesis was carried out from the nodal explants of Cleome gynandra L. The nodal explants were grown on MS medium supplemented with different concentrations of BAP or KIN ranging from $5-25$ $\mu \mathrm{M}$. Both the cytokinins had more or less similar effect. However, BAP was found to have little higher effect for shoot multiplication when compared to KIN. Maximum number of 13.2 shoots per explant and mean shoot length of $6.6 \mathrm{~cm}$ with $90 \%$ shoot induction frequency were obtained from the nodal explants on MS medium containing $10 \mu \mathrm{M}$ BAP. Maximum number of 11.75 shoots per explant and mean shoot length of $6.62 \mathrm{~cm}$ with $83.3 \%$ shoot induction frequency were obtained from the nodal explants on MS medium containing $15 \mu \mathrm{M}$ KIN.

\section{Acknowledgement}

The authors wish to thank the University Grants Commission, New Delhi for providing financial assistance to carry out Major Research Project on Cleome gynandra L. (F.No. : 43-143/2014(SR) dated 21.07.2015, University Grants Commission, New Delhi).

\section{References}

[1] S. Thenmozhi, U. Subasini, S. Kameshwaran, M. Dhanalakshmi, G. Victor Rajamanickam, "Morphoanatomical and preliminary phytochemical studies of leaves of Gynandropsis pentaphylla Linn.," Int. J. of Pharm. \& Life Sci. (IJPLS), Vol. 4(7), pp.2800-2809, 2013.

[2] T. Shanmuganathan, and A.V.P. Karthikeyan, "Free radical scavenging Activity of aqueous and ethanolic extracts of wild and L-arginine treated Cleome gynandra L," International Journal of Pharma Sciences and Research, Vol. 5(7), pp.346-349, 2014.

[3] T. Shanmuganathan, and A.V.P., Karthikeyan, "Antimicrobial activity of in vivo and in vitro plants of Cleome gynandra L.," World Journal of Pharmacy and Pharmaceutical Sciences, Vol. 5(7), pp.948-953, 2016.

[4] T. Shanmuganathan, A.V.P. Karthikeyan, "Phytochemical Analysis and antioxidant activities of in vivo and in vitro Shoots of Cleome gynandra L," International Journal of Science and Research, Vol. 5(6), pp.208-211, 2016.

[5] S. S. Mishra, S.K. Moharana, and M.R. Dash, "Review on Cleome gynandra". International Journal of research in pharmacy and chemistry, Vol. 1(3), pp. 681-89, 2011.

[6] T. Kalaivani, C. Rajasekaran and Lazar Mathew, "In vitro free radical scavenging potential of Picrorhiza kurroa", Journal of Pharmacy Research, Vol. 3(4), pp. 849-854, 2010.

[7] R.T. Narendhirakannan, M. Kandaswamy and S.Subramanian, "Antiinflammatory activity of Cleome gynandra L. on hematological and cellular constituents in adjuvant induced arthritic rats", Indian J. Med. Food, Vol. 8(1), pp. 93-99, 2005.

[8] J. Anburaj, C.R. Singh, T. Kuberan, C. Sundaravadivelan, P. Kumar, "Effects of plant growth regulators on callus induction from leaf explants of Cleome viscose," RJPBCS, Vol. 2, pp.576-583, $2011 \mathrm{a}$.

[9] J. Anburaj, C.R. Singh, S. Sundarraj, S. Kannan, "In vitro regeneration of Cleome viscosa - an important medicinal herb," J. Cell. Mol. Biol. 9, pp.37-44, 2011 b.

[10] C. Simões, A.S. Santos, N. Albarello, S.F.L. Figueiredo, "Shoot organogenesis and plantlet regeneration from stem explants of Cleome rosea Vahl (Capparaceae)," J. Plant Biotechnol., Vol. 6, pp.3199-3204, 2004.

[11] N. Albarello, C. Simões, P.F.G. Rosas, T.C. Castro, M.G. Gianfaldoni, C.H. Callado, E. Mansur, "In vitro propagation of Cleome spinosa (capparaceae) using explants from nursery-grown seedlings and axenic plants," In Vitro Cell. Dev. Biol. Plant, Vol. 42, pp.601606, 2006.

[12] Y. Qin, F. Zeng, X. Sun, Y. Feng, C. Yang, "Propagation of Cleome spinosa Jacq. through tissue culture. J. Microbiol. Vol. 1(5), pp.1319-1327, 2012.

[13]N. Albarello, C. Simões, T.C. Castro, C.R.M. Gayer, M.G.P. Coelho, R.S. Moura, E. Mansur, "Antiinflammatory and antinociceptive activity of fieldgrowth plants and tissue culture of Cleome spinosa (Jacq.) in mice," J. Med. Plants Res., Vol. 7(16), pp.1043-1049, 2013.

[14] N.S. Rathore, N. Rathore, N.S. Shekhawat, "In vitro propagation and micromorphological studies of Cleome gynandra: a $\mathrm{C} 4$ model plant closely related to Arabidopsis thaliana," Acta Physiol. Plant. DOI 10.1007/s11738-013-1301-2, 2013.

[15] C. Simões, N. Albarello, C.H. Callado, T.C. Castro, E. Mansur, "Somatic embryogenesis and plant regeneration from callus cultures of Cleome rosea Vahl.," Vol. 53(3), pp.679-686, 2010.

[16] L.S. Cordeiro, C. Simões, N. Albarello, "Cryopreservation of Cleome rosea Vahl in vitro roots using the vitrification technique," Vol. 65(3), pp.345, 2012.

[17] T. Murashige and F. Skoog, "A revised medium for rapid growth and bioassay with tobacco tissue culture", Physiologia Plant., Vol. 15, pp. 473-497, 1962.

[18] K. A. Gomez and K. A. Gomez, "Statistical procedures for agricultural research with emphasis on Rice", Philippines International Rice Research Institute, Los Bans.Grieve, A Modern Herbal. Penguin, 1976.

[19] W.E. Gnanaraj, J.M. Antonisamy, R.B. Mohanamathi, K.M. Subramanian, "In vitro clonal propagation of Achyranthes aspera L. and Achyranthes bidentata Blume using nodal explants," Asian Pacific Journal of Tropical Biomedicine, pp.1-5, 2012.

[20] Jeyaraj Anburaj, Chinnappan Ravinder Singh, Shenbagamoorthy Sundarraj and Soundarapandian Kannan, "In vitro regeneration of Cleome viscosa - an important medicinal herb," Journal of Cell and Molecular Biology, Vol. 9(1), pp. 37-44, 2011.

[21] Jitendra Mehta, Monika Sain, Banwari Lal Mathuriya, Ritu Naruka, Ambika Kavia and Dev Ratan Sharma, "Rapid micropropagation and callus induction of Terminalia bellerica Roxb. - An endangered plant," Asian Journal of Plant Science and Research, Vol. 2(3), pp.364-368, 2012.

[22]A. V. P. Karthikeyan, T. Shanmuganathan, and C. Karthi, "In vitro propagation of Cleome gynandra L. 


\section{International Journal of Science and Research (IJSR) \\ ISSN (Online): 2319-7064}

Index Copernicus Value (2015): 78.96 | Impact Factor (2015): 6.391

through direct organogenesis," Vol. 3(7), pp.1368-1372, 2014.

[23] S.S. Subramanian, K.R. Monzhi, B.C. Chandar, A.N. Sundar, C.M. Devi, "Rooting experiments on stem cuttings of Vicoa indica (L.) DC. An important medicinal plant," J Biosci Res. Vol. 2(1), pp.35-37, 2011.

[24]P. Velayutham, and C. Karthi, "GC-MS Profile of in vivo, in vitro and fungal elicited in vitro leaves of Hybanthus enneaspermus (1.) f. Muell," International Journal of Pharmacy and Pharmaceutical Sciences, Vol.7(10), pp.260-267, 2015.

[25]P. Nalini and P. Velayutham, "In vitro Mass Propagation of Enicostemma littorale Blume from Shoot Tip Explants", Journal of Biology Agriculture and Healthcare, Vol. 3(5), pp. 72-79, 2013.

[26]P. Velayutham and B.D. Ranjitha Kumari, "Direct shoot regeneration from leaf explants of chicory (Cichorium intybus L.)", Plant Cell Biotech Mol. Biol., Vol. 4(3\&4): 125-130, 2003.

[27] H. Padmapriya, A.V.P. Karthikeyan, G. Jahir Hussain, C. Karthi and P. Velayutham, "An efficient protocol for in vitro propagation of Solanum nigrum L. from nodal explants", Journal of Agricultural Technology, Vol. 7(4), pp. 1063-1073, 2011.

[28] G. Ahmed, P.K. Roy, A.N. Mamun, "High frequency shoot regeneration from nodal and shoot tip explants in Holarrhena antidysenterica L.," Vol. 39, pp. 1322 1324, 2001.

[29] O.L. Gamborg, R.A. Miller, K. Ojima, "Nutrient requirements of suspension culture of soybean root cells," Experimental Cell Research., Vol. 50, pp.155158, 1968.

[30]K. Ghanti, C.P. Kaviraj, R.B. Venugopal, F.T.Z. Jabeen, S. Rao, "Rapid regeneration of Mentha piperita L. from shoot tip and nodal explants," Indian J of Biotechnology, Vol. 3, pp. 594-598, 2004.

[31] S. Pandey, and V.S. Jaiswal, "Micropropagation of Terminalia arjuna Roxb. From cotyledonary nodes," Indian J Exp Biol., Vol. 40(8), pp. 950-953, 2002.

\section{Author Profile}

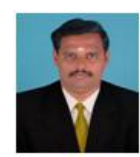

Dr. A.V.P. Karthikeyan, Plant Biotechnologist has specialized in Plant Tissue Culture. He did his Ph. D. in Botany (2001) from Bharathidasan University, Tiruchirappalli and M. Sc. in Botany (1996) from St. Joseph ${ }^{\text {es }}$ College, Tiruchirappalli, Tamil Nadu, India. Currently he is working as an Assistant Professor in P.G. \& Research Department of Botany, Government College, Karur, Tamil Nadu, India from 2007 until now.

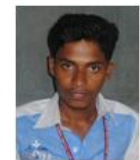

Sudan, a full time Research Scholar, P.G. \& Research Department of Botany, Government Arts College, Karur. Working as a JRF in UGC - Major Research Project. He received academic proficiency medal in for his PG course at Government Arts College, Karur. 